\title{
EXPERIMENTS ON THE HUMANE KILLING OF CRABS
}

\author{
By John R. Baker, D.Sc. \\ Department of Zoology, University Museum, University of Oxford
}

(Plates I and II)

The main purpose of the work described in this paper was to find a humane way of killing crabs for eating, but the method that resulted from the investigation is applicable also in the biological laboratory, unless it is necessary that the nerve ganglia should be intact.

\section{MATERIAL}

The whole of the work was done on the edible crab, Cancer pagurus L.

In order to get reliable results, capable of repetition by others, it was necessary to work with fully active crabs, and this could only be done near the sea. The whole of the work reported in this paper was done at the Marine Biological Laboratory, Plymouth, at the end of August 1953.

Crabs brought in by fishermen were placed in a large outdoor aquarium, plentifully supplied with running sea water. No crab was used unless it gave evidence of full normal activity. The first piece of evidence required was that it should make vigorous attempts to avoid capture by a net.

Each crab, when so captured, was brought from the aquarium into the laboratory and subjected to further tests. It was found best to place the crab the right way up in a large basin of sea water. Care was taken to devise tests that would be practical and reliable. A normally vigorous crab gives these responses to stimuli:

Ocular reaction. The crab retracts the Ist and/or 2 nd antennae when the hand is passed from one side of the animal to the other above the eyes. (The hand must not touch the animal.)

Antennal reaction. The crab retracts the Ist antennae when the distal (pigmented) end of the middle joint of the protopodite of this appendage is gently touched with a seeker.

Maxilliped reaction. The crab folds the 3 rd maxillipeds towards the body and/or brings the chelae towards one another when the 3 rd maxilliped is gently pressed away from the body with a seeker.

Pincer reaction. The crab grasps a hard object placed so as to touch the tubercles on the propodite of the chela.

The first two tests provide evidence that the cerebral ganglion is intact, while the third and fourth do the same for the posterior ganglion. These were 
the tests usually applied, though others were sometimes used. No crab was used in the experiments unless it showed normal responses.

The twenty-five crabs subjected to the main control and experimental procedures are distinguished in this paper by the serial letters A to Y. Details of the experiments with these crabs are given in Table I on p. 18. Two crabs which were treated in such a way that the experiments could not conveniently be summarized in the same table are designated AA and BB.

\section{MeTHODS}

Fishmongers boil crabs in a solution of common salt approximating in concentration to sea water. At the seaside, sea water is sometimes used. In the experiments described in this paper, sufficient tap water was added to $288 \mathrm{~g}$ of culinary bar-salt to make 81 . of solution. This solution (approximately $3.6 \%$ sodium chloride solution) was heated in a metal vessel by a large gas burner.

All the crabs used in this investigation, except one, were boiled in this solution, most of them after preliminary treatment intended to render them insensible. It was thought advisable to watch carefully for movements of the appendages during the process of boiling, and the temperature was therefore kept somewhat lower than the actual boiling-point. The mean temperature at the moment of immersion was $96^{\circ} \mathrm{C}$. Although the gas-burner was left on, the temperature was usually somewhat lower (mean, $92^{\circ} \mathrm{C}$ ) after the lapse of $6 \mathrm{~min}$, when in every case except one all movement was at an end. The immersion of crabs in this very hot water is called 'boiling' for short throughout this paper.

It was found convenient to hold the animal in tongs, nearly horizontally, the right way up, during immersion. Crab A was placed upside down.

The special procedures intended to render the crabs insensible are described in the appropriate places below.

\section{RESULTS}

\section{Controls (no Treatment before Boiling)}

Seven crabs, A to G, were boiled alive without previous treatment.

In all cases the time elapsing between the moment of immersion and the occurrence of the last movement was carefully noted.

When an untreated crab is placed in the hot water, the autotomy-reaction occurs immediately in the chelae and walking legs. All these ten appendages are instantly raised and pressed against the edges of the carapace. This movement is complete in about Io sec. If it is powerful enough, the appendage breaks off at the fracture-plane in the basi-ischium. The greater part of the appendage falls away, either at once or after a short lapse of time. While the appendage is held firmly against the carapace, it cannot move until it breaks. When it breaks, the stump is free to move, and it often does so. There is, 
however, no continuous movement. On the contrary, all that one observes is an occasional twitch. In general, the reaction to the heat is simply a powerful, continuous contraction of the extensor muscles of the appendages that have fracture-planes; that is to say, the chelae and walking legs.

The following are the periods (in minutes and seconds, to the nearest $5 \mathrm{sec}$ ) that elapsed between immersion and the last movement: $0.15,4.15,6.50$, $2 \cdot 45,2 \cdot 35,2 \cdot 45,0 \cdot 10$ (mean, $2 \cdot 50$ ).

Although these periods were always measured, they seem to have little value. It seems probable that apart from the contraction of the extensors, movement is not initiated by the nervous system. It seems much more likely that it is caused by the direct effect of the heat on the substance of the muscles. The following experiment was done to test this hypothesis. A crab (AA) was exposed to the vapour of chloroform until it appeared to be dead. On removal from the vapour it made no spontaneous movement, not even a flicker of the Ist antennae or of the flagella of the maxillipeds. No response was given to any of the tests. This crab was boiled in the usual way. No appendage was thrown off by autotomy, but the last movement occurred 2 min $5 \mathrm{sec}$ after immersion. It seems certain that this was merely the result of the shortening of a muscle of a dead crab under the influence of heat.

Movement of an appendage was also occasionally observed to be caused by the expansion and escape of air contained in the branchial chambers.

For these reasons it was concluded that the timing of the last movement was useless, and that it would be best to concentrate attention on the autotomyreaction, which is governed by the nervous system.

The total number of appendages thrown off by each crab is shown in Table I (p. I8). There is not much difference between one appendage and another in the tendency to be thrown off on boiling.

Among the seven control crabs, only one appendage (a $4^{\text {th }}$ walking leg) was absent by previous injury when boiling started. Of the sixty-nine appendages present, forty-two $(6 \mathrm{r} \%)$ were thrown off on boiling.

\section{Immersion in Strong Salt Solution before Boiling}

It was found by Aaser (n.d.) that if lobsters are placed in a strong solution of common salt ( $350 \mathrm{~g}$ to each litre of water), they may subsequently be boiled without showing any other reaction than a single flip of the abdomen. Quite short periods in the strong salt solution sufficed-a minute or even less.

In the present investigation the same method was tried on crabs. Exactly the same salt solution as that used by Aaser was employed. The temperature of the solution was $18-19^{\circ} \mathrm{C}$.

Five crabs, $\mathrm{BB}$ and $\mathrm{H}$ to $\mathrm{K}$, were each placed in strong salt solution for Io min. The experiments were done separately, so that full attention could be concentrated on the reactions of each animal.

When the crabs were placed in the strong salt solution, the first antennae 
were at once strongly retracted and could therefore give no response. In general, the animals then at first remained still. After a short lapse of time (half a minute or so) some movement of the walking legs started, with feeble locomotion in some cases. No response was given to stimulation of the maxillipeds, and the pincer reaction was very weak. Spontaneous movement had ceased before the ro min had elapsed.

\section{Table I. Degree of Autotomy after Different Treatments}

\begin{tabular}{|c|c|c|c|c|c|}
\hline \multirow[b]{2}{*}{ Crab } & \multirow[b]{2}{*}{ Sex } & \multirow[b]{2}{*}{$\begin{array}{c}\text { Width of } \\
\text { carapace } \\
\text { (cm.) }\end{array}$} & \multirow[b]{2}{*}{ Treatment before boiling } & \multicolumn{2}{|c|}{$\begin{array}{l}\text { No. of autotomy } \\
\text { appendages }\end{array}$} \\
\hline & & & & $\begin{array}{l}\text { Absent } \\
\text { before } \\
\text { boiling }\end{array}$ & $\begin{array}{l}\text { Lost by } \\
\text { autotomy } \\
\text { on boiling }\end{array}$ \\
\hline A & 오 & 12 & None (control) & ० & 2 \\
\hline B & 우 & I6 & None (control) & ० & 8 \\
\hline C & 우 & I8 & None (control) & o & 9 \\
\hline $\mathrm{D}$ & o & 14 & None (control) & 0 & 7 \\
\hline $\mathrm{E}$ & $\hat{0}$ & I4 & None (control) & 0 & 7 \\
\hline $\mathrm{F}$ & q & I6 & None (control) & 0 & 3 \\
\hline G & 우 & I5 & None (control) & I & 6 \\
\hline $\mathrm{H}$ & 우 & I6 & Immersion in strong salt solution & I & 4 \\
\hline I & 우 & I6 & Immersion in strong salt solution & 0 & IO \\
\hline $\mathrm{J}$ & 우 & I8 & Immersion in strong salt solution & 0 & Io \\
\hline $\mathrm{K}$ & $\hat{0}$ & I6 & Immersion in strong salt solution & 0 & 9 \\
\hline $\mathrm{L}$ & 호 & I9 & Immersion in tap water & 0 & 6 \\
\hline M & 0 & II & Gradual increase of temperature to boiling & 0 & 3 \\
\hline $\mathrm{N}$ & 우 & I6 & Piercing of brain at $85^{\circ}$ & 0 & 5 \\
\hline $\mathrm{O}$ & 우 & I7 & Piercing of brain at $85^{\circ}$ and v.n.-m. at $110^{\circ}$ & I & I \\
\hline $\mathbf{P}$ & $\hat{0}$ & 12 & Piercing of brain at $85^{\circ}$ and v.n.-m. at $110^{\circ}$ & 0 & 0 \\
\hline Q & 0 & I4 & Piercing of brain at $85^{\circ}$ and v.n.-m. at $110^{\circ}$ & 0 & 0 \\
\hline$\hat{\mathrm{R}}$ & $\hat{0}$ & 14 & Piercing of brain at $85^{\circ}$ and v.n.-m. at $110^{\circ}$ & I & o \\
\hline $\mathrm{S}$ & $0^{x}$ & 12 & Piercing of brain at $85^{\circ}$ and v.n.-m. at $110^{\circ}$ & $\circ$ & 2 \\
\hline $\mathrm{T}$ & 우 & I5 & Piercing of brain at $85^{\circ}$ and v.n.-m. at $110^{\circ}$ & ० & I \\
\hline $\mathrm{U}$ & 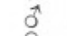 & 14 & Piercing of v.n.-m. at $85^{\circ}$ & 0 & o \\
\hline V & 우 & I6 & Piercing of v.n.-m. at $85^{\circ}$ & I & o \\
\hline W & 0 & I6 & Piercing of brain at $60^{\circ}$ and v.n.-m. at $85^{\circ}$ & ० & 0 \\
\hline $\mathrm{X}$ & 우 & I5 & Piercing of brain at $60^{\circ}$ and v.n.-m. at $85^{\circ}$ & 0 & ० \\
\hline $\mathrm{Y}$ & $\hat{0}$ & I7 & Piercing of brain at $60^{\circ}$ and v.n.-m. at $85^{\circ}$ & 0 & o \\
\hline
\end{tabular}

The piercing angles given are only approximate. v.n.-m.: ventral nerve-mass.

The crab BB was returned to sea water. It soon gave the ocular and antennal reactions again, but irreparable damage had been done, and it was found to be dead about $6 \frac{1}{2} \mathrm{~h}$ later.

The other four crabs ( $\mathrm{H}$ to $\mathrm{K}$ ) were boiled immediately after they had been taken from the strong salt solution. Before the experiment they had thirty-nine appendages capable of autotomy, only one walking limb of one animal having been absent; thirty-three appendages were thrown off during boiling. The percentage of autotomy, $85 \%$, was even higher than in the controls.

It is clear that short immersion in strong salt solution is not a suitable method for rendering crabs insensible. The difference from lobsters is no doubt caused by the far greater protection of the gills in the crab. The effect 
of the strong salt is only slowly felt if the respiratory current is weak or intermittent, or if there is much air in the branchial chambers.

The American crab, C. magister, which lives below low-tide mark in Pacific seas just as $C$. pagurus does in ours, and is thus not subjected in nature to any but very small changes in the osmotic pressure of the surrounding medium, is unable to regulate the osmotic pressure of its blood against water of higher salinity than the sea (Jones, I94I). If $C$. pagurus were left for a sufficient period in strong salt solution, it would eventually die from increase of the osmotic pressure of its blood, as indeed crab BB died; but there is no likelihood that this slow death would be painless.

\section{Immersion in Cool Tap Water before Boiling}

It was thought worth while to find whether a crab could be rendered insensible quickly by immersion in tap water.

The water was at $17^{\circ} \mathrm{C}$. The crab $(\mathrm{L})$ was much more active than the ones placed in strong salt solution. The respiratory current was strong. Some unco-ordinated movement occurred (the animal grasped a maxilliped with the chela of the opposite side, and later it moved its maxillipeds from side to side). The animal moved about from time to time.

At the end of Io min the crab was boiled. Of the ten autotomy-appendages, six were thrown off.

From a study of $C$. pagurus placed in water of lower salinity than that of the sea, Hukuda (1932) concluded that the gills are permeable to salts in these circumstances, so that the saline concentration of the blood drops. The placing of the animal in tap water must result in eventual death from loss of salts from the blood, but the experiment recorded in this paper shows that the process is not a quick one.

\section{Gradual Increase of Temperature to Boiling}

According to Sinel (n.d.), if a lobster is placed in weak salt solution and the temperature is gradually raised, the animal becomes lethargic and dies at about $27^{\circ} \mathrm{C}$. The heating to this temperature took about $3 \mathrm{~min}$ in Sinel's experiments. Sinel recommends this as a humane way of killing both lobsters and crabs, though he appears not to have made experiments with crabs. This result was supported by an experiment carried out on lobsters under the auspices of the Trondhjem Society for the Protection of Animals (Anon., n.d.).

Aaser (n.d.) put lobsters in a weak solution of common salt at $9^{\circ} \mathrm{C}$ and gradually heated the water. They moved about at first, but their activity gradually decreased and they died between $38^{\circ}$ and $45^{\circ} \mathrm{C}$. Aaser found that in general a lobster immersed in water at $26^{\circ} \mathrm{C}$ continues to respond to stimuli for about $\frac{3}{4} \mathrm{~h}$.

In the present investigation, a crab $(\mathrm{M})$ was placed in a $3.6 \%$ solution of common salt at $19^{\circ} \mathrm{C}$. The solution was gradually warmed. The temperature 
of $27^{\circ} \mathrm{C}$ was reached in about $7 \mathrm{~min}$. The crab was still active. The temperature was increased gradually till boiling point was reached in $28 \mathrm{~min}$. The crab was active at $26^{\circ} \mathrm{C}$ and continued to move about as the temperature rose higher. It attempted to escape by pushing backwards against the sides of the vessel. At $32^{\circ} \mathrm{C}$ the movements began to become unco-ordinated. At $34^{\circ} \mathrm{C}$ it was much less active and there was no locomotion; both chelae were thrown off. The Ist walking limb of the left side was subsequently lost. At $40^{\circ} \mathrm{C}$, reached in $8 \frac{1}{2} \mathrm{~min}$, the last movement was seen (very slight change of position of the last walking limb); no response was given to stimuli.

Crabs only perform autotomy when they are vigorous, and it is probable that if the experiment had been performed on a specimen obtained from a fishmonger, no limb would have been thrown off. However, this method of killing crabs does not commend itself on humanitarian grounds.

\section{Piercing the Nerve Ganglia before Boiling}

Some years ago I visited Billingsgate fishmarket and witnessed the 'sticking' of two crabs before boiling (Baker, 1949). A steel awl mounted in a wooden handle was used. The animal was laid on its back and the point of the awl was pushed through the exoskeleton in two places, referred to by the operator as the 'mouth' and 'back passage'. I noted where these points were. The anterior one was the very small depression in the middle line at the posterior end of the sternum of Ist antennal segment, immediately in front of the epistoma (P1. I, fig. I). The posterior one was the large depression in the middle line at the posterior end of the sternum of the segment of the chelae (Pl. I, fig. 2). It was evident that the awl would necessarily damage the two main nerve centres of the body, the brain (fused cerebral ganglia) and ventral nerve mass. What I saw encouraged me to believe that it would be useful to investigate this method.

I made a special dissection to find out in what direction the awl should be pointed in order to reach the two ganglia from the depressions mentioned.

The animal must be placed as horizontally as possible on its back. It would be best to have a bench with shaped hollows in it, suitable for holding crabs of various sizes horizontally. However, it suffices in the laboratory to twist a duster into a roll and to shape this in a ring, against which the edges of the carapace can rest.

The awl must of course be kept in the sagittal plane of the animal. The angle at which it is held will be described as follows. If it is held vertically, the angle is $90^{\circ}$. If the handle of the awl is moved forwards, a lower angle is recorded, till $0^{\circ}$ would be reached if the point of the awl were directed horizontally backwards.

I have had a special awl made for sticking crabs. The steel point is fine, so as to make as small a hole as possible and thus allow little blood to escape. It is $25 \mathrm{~mm}$ long. This length is designed to reach easily the ventral nerve- 
mass of the largest crab. The wooden handle is $30 \mathrm{~cm}$ long. This length is designed to make it possible to pierce the largest crab without the animal being able to reach one's fingers with its pincers. With a crab of average size, a push of about $4 \frac{1}{2} \mathrm{~mm}$ would suffice to penetrate the brain, while about $9 \mathrm{~mm}$ would be required for the ventral nerve-mass. A push of $13 \mathrm{~mm}$ should suffice for the ventral nerve-mass of the largest crab. The awl cannot be inserted up to the hilt, because the latter will not enter the depression in the sternum of the segment of the chela; that is why the steel point is made longer than $13 \mathrm{~mm}$.

It is not necessary (nor indeed possible) to observe the piercing angles very exactly, for the brain is close to the point of the awl when one starts to push, and the ventral nerve-mass, though deeper, is much larger.

When the piercing has been done, the handle of the awl should be moved about slightly in all directions, to complete the damage to the ganglia.

In the first experiment (crab N), the brain only was pierced, at about $85^{\circ}$. The antennal response was now no longer given, but the animal naturally still gave the maxilliped and pincer responses. The crab was at once boiled. It lost five of its ten autotomy limbs. Destruction of the brain cannot prevent autotomy, for this process is mediated by the ventral nerve-mass, as Frederic showed long ago (I882).

Both ganglia of six crabs $(\mathrm{O}$ to $\mathrm{T})$ were pierced in the next series of experiments. The brain was pierced at about $85^{\circ}$, the ventral nerve-mass at about $1 \mathrm{IO}^{\circ}$. No maxilliped or pincer responses were observed in any of these crabs after piercing, but there was some slight spontaneous flickering of the flagella of the maxillipeds of some of them. There was also at first some spontaneous twitching of the distal parts of the Ist antennae. One of the crabs $(\mathrm{P})$ gave a very slight antennal response, another (S) an ocular response.

Each of these six crabs was boiled directly its responses had been observed. Two of them each lacked one chela before boiling; there were thus fifty-eight autotomy limbs among the six crabs. Of these, four $(7 \%)$ were thrown off during boiling. Three of the six crabs lost no appendage.

These results were encouraging, but both the responses and the autotomy showed that the direction of the awl was not quite accurate. Another dissection was made, and it was decided to try about $60^{\circ}$ for the brain and about $85^{\circ}$ for the ventral nerve-mass. In piercing the latter at $85^{\circ}$, it is important not to try to insert the point of the awl into the very bottom of the hole in the sternum, for the depression turns posteriorly, and the awl will have to be held at a lower angle than $85^{\circ}$ if its point is to touch the bottom. One should hold the awl at about $85^{\circ}$ and place it as far back in the hole as is consistent with the maintenance of this angle.

In two crabs ( $\mathrm{U}$ and $\mathrm{V})$, the posterior ganglion only was pierced. No maxilliped or pincer reaction was given, but $\mathrm{V}$ gave the ocular reaction and at first showed some spontaneous twitching of the distal parts of the Ist antennae. 
This was only to be expected, since the brain was intact. On boiling, neither crab lost any appendage.

In a final series of experiments, both the brain and the ventral nerve-mass of three crabs (W to Y) were pierced in the new directions (P1. II, figs. I and 2). These new directions appeared to be correct, for none of these three crabs gave any response to stimuli. There was, however, some slight spontaneous movement of small parts, such as has already been mentioned: namely, a twitching of the distal extremity of the Ist antennae, and a flickering to and fro of the exopodites of the maxillipeds. In addition, crab Y slightly moved its mandibles and the basal parts of its maxillipeds. It will be recalled that the mandibles receive some innervation from the little paraoesophageal ganglia, which cannot be pierced from outside the animal.

Each of the crabs W to $\mathrm{Y}$ was boiled directly its responses and spontaneous movements had been noted. No appendage was absent before boiling. Of the thirty available appendages, none was lost on boiling.

The five crabs U to Y possessed forty-nine autotomy limbs before boiling. The ventral nerve-mass of each of these crabs was pierced at about $85^{\circ}$. It is to be noted that not a single limb was lost on boiling.

From a culinary point of view, it is desirable to prevent the escape of blood when the crab is pierced, partly because the blood coagulates on the surface of the animal when it is boiled and thus disfigures it, and partly because it is thought that the taste of the crab would be affected if blood were lost.

Care must be taken when piercing the brain of a small crab, or the point of the awl will pass through the dorsal part of the carapace and thus allow the escape of blood.

If the piercing is done carefully, with a fine-pointed awl, little blood should be lost. It is a good plan to fold the abdomen back into its normal position after piercing the ventral nerve-mass, and to fix it there by tying a string round the animal. The posterior awl-hole will thus be closed, and since air cannot enter it, blood cannot easily escape from the anterior hole.

\section{Note on Accidental Autotomy}

Two of the crabs (O and $\mathrm{R})$ threw off a chela each at or immediately after the piercing of the ventral nerve-mass at $11^{\circ}$ (before boiling). Autotomy did not occur with any of the five crabs in which this ganglion was pierced at $85^{\circ}$. Frederic (1882) remarks that on one occasion autotomy occurred when he applied an electric shock to the ventral nerve-mass of Carcinus.

\section{Discussion}

The evidence from responses to stimuli, and especially from autotomy, suggests that the best method of rendering a crab insensible is to pierce the brain and ventral nerve-mass with an awl in the way directed. 
The experiments of Bethe (1898) showed that the brain of Carcinus maenas is a reflex-inhibiting organ, which to a large extent controls the adaptive responses of the animal. Those who associate cephalic dominance with cephalic consciousness will be inclined to pierce the brain before the ventral nerve-mass. If so, the appendages that are innervated by the ventral nervemass will move actively until the latter has been pierced.

It is fortunate that the method that seems best from the point of view of animal welfare should also commend itself to fishmongers and canners, because it enables crabs to be boiled without losing appendages, however vigorous they may be, and without the waste of time involved in other methods that have been suggested.

The technique of piercing could be taught in $15 \mathrm{~min}$ to any person of ordinary intelligence who was accustomed to handling crabs. Preliminary demonstrations could conveniently be given on a preserved specimen.

It is particularly to be noted that a method that is suitable for the crab may be quite unsuitable for the lobster, and conversely. This is because the crab has only a single ventral nerve-mass instead of a chain of twelve separate ganglia, while the gills of the lobster are much more directly exposed to the environment than those of the crab.

The work was carried out under the auspices of The Universities' Federation for Animal Welfare, and with the Federation's financial support. I thank the Director and Staff of the Marine Biological Laboratory, Plymouth, for helping me in every possible way, especially by ensuring a regular supply of very vigorous crabs. Mr P. L. Small took the photographs (Plates I and II).

\section{SUMMARY}

The following methods intended to render crabs (Cancer pagurus) insensible before boiling were tried: immersion in strong salt solution, immersion in tap water, gradual increase of the temperature to boiling, and piercing of the brain and ventral nerve-mass with a steel-pointed awl. The responses of the crabs to stimuli, and especially the autotomy reaction on boiling, were carefully observed. The experiments showed that the best method is to pierce the brain and ventral nerve-mass. It is important to hold the awl at the proper angles when inserting it in the two positions.

\section{REFERENCES}

AASER, C. S., n.d. (about 1947). Koking av hummer. Published by Utgitt av Foreningen til Dyrenes Beskyttelse, Karl Johansgt. I6, Oslo.

Anon., n.d. Kokning av skalldyr. Published by the Trondhjem Society for the Protection of Animals.

BAKER, J. R., I949. The sticking of crabs. UFAW Courier, no. 3, pp. 17-I8. 
Bethe, A., 1898. Das Centralnervensystem von Carcinus maenas. Ein anatomischphysiologischer Versuch. Arch. mikr. Anat., Bd. 51, pp. 382-452.

FREDERIC, L., I882. Amputation des pattes par mouvement réflexe chez le crabe. Arch. Biol., Paris, T. 3, pp. 235-40.

HukUdA, K., 1932. Change of weight of marine animals in diluted media. F. exp. Biol., Vol. 9, 6I-68.

JoNES, L. L., I94I. Osmotic regulation in several crabs of the Pacific coast of North America. F. cell. comp. Physiol., Vol. 18, pp. 79-92.

Sinel, J., n.d. (about I9I4). The Killing of Crabs and Lobsters for Table. Published by the Royal Society for the Prevention of Cruelty to Animals.

\section{EXPLANATION OF PLATES}

\section{Plate I}

Fig. I. The anterior end of a crab, in ventral view. The sternum of the segment of the Ist antennae has been outlined in ink in the photograph. The arrow points to the small depression in which the point of the awl must be inserted to pierce the brain.

Fig. 2. Ventral view of a crab. At the posterior end of the sternum of the segment of the chelae is the large depression (marked by an arrow) in which the point of the awl must be inserted to pierce the ventral nerve-mass.

\section{Plate II}

Fig. I. Piercing the brain of a crab with the specially designed awl.

Fig. 2. Piercing the ventral nerve-mass. 

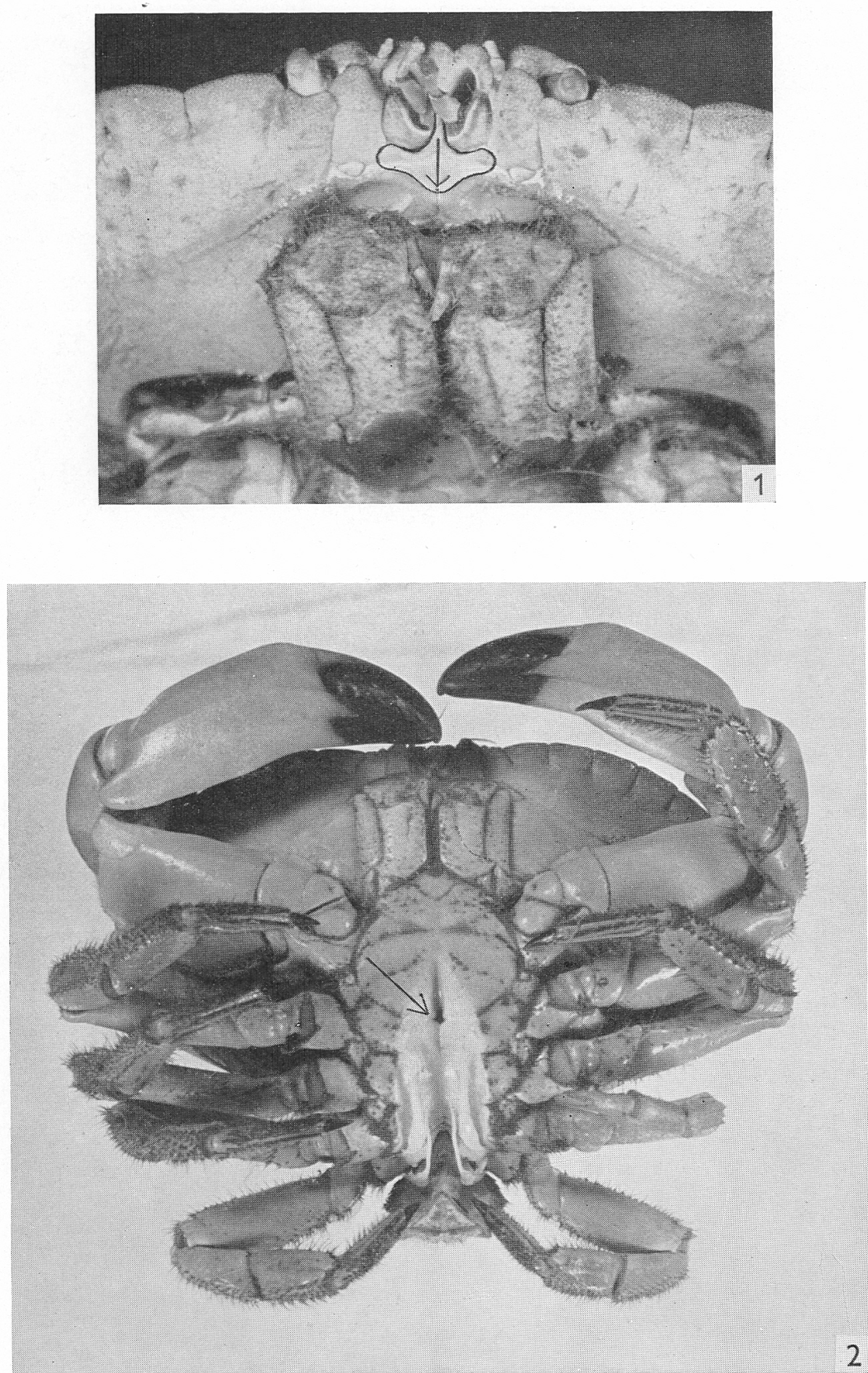

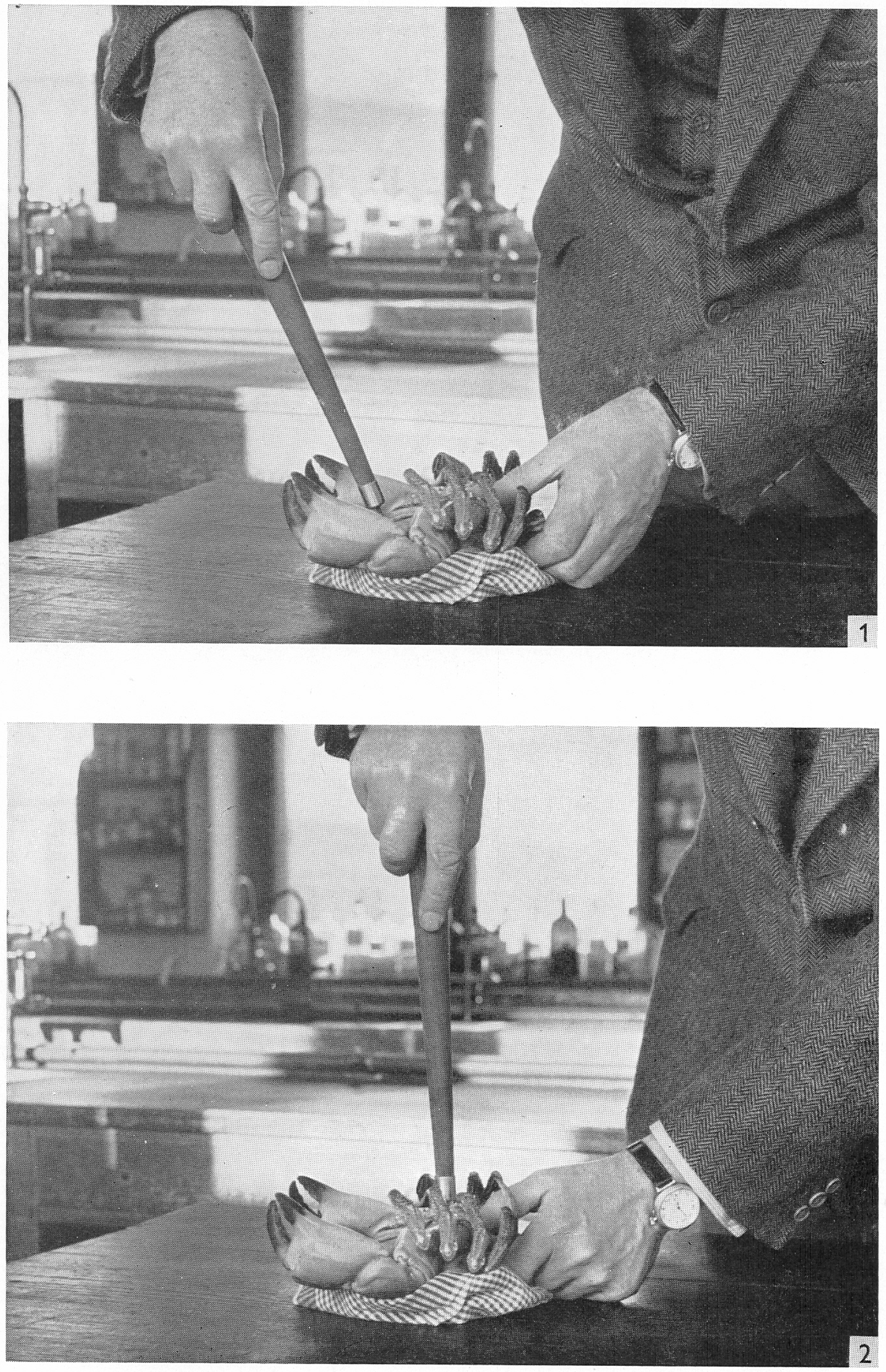